\title{
The Prohibition on Constitutional Review by the Judiciary in the Netherlands in Critical Perspective: The Case and Roadmap for Reform
}

\author{
Gerhard van der Schyff ${ }^{\star}$
}

(Received 25 June 2019; revised 12 November 2019; accepted 13 November 2019)

\begin{abstract}
Paradoxically, at roughly the same time in the Netherlands the amendment bill to introduce constitutional review by the judiciary of acts of parliament lapsed in 2018, the State Commission on the Parliamentary System recommended that such review be introduced. This Article analyzes Dutch exceptionalism on the topic of prohibiting constitutional review and comes to the conclusion that it cannot be justified. Focusing on the nature of constitutional change in the country, the recommendation is made that the quest for reform should start with the courts, and not with the constitutional legislature, as has been the case to date.
\end{abstract}

Keywords: Constitutional exceptionalism; constitutional review; The Netherlands; constitutional change; constitutional reform

\section{A. Exceptionalism in the Spotlight}

Writing in 1947, legal scholar P.J. Oud explained that the practice in the United States of America to allow the courts to judge the constitutionality of acts of parliament was quite rare, as most countries restricted constitutional review to their legislatures. ${ }^{1}$ American exceptionalism in this regard is something of the past, as the judicial review of constitutions has become the common currency in modern-day constitutionalism. ${ }^{2}$ Today, American exceptionalism has been replaced by Dutch exceptionalism. This is because the Netherlands is one of the few constitutional democracies that still prohibits the courts from reviewing the constitutionality of acts of parliament.

The prohibition on review, contained in Article 120 of the Dutch Constitution, was confirmed in $2018 .^{3}$ In that year, the House of Representatives ruled that the most serious attempt to date to amend the prohibition had lapsed. ${ }^{4}$ This brought to an end a remarkably long trajectory of sixteen years, as the constitutional amendment Bill had been tabled in 2002. The House of Representatives made the unusual decision that the Bill had ceased to be valid because, although it passed its first reading, it never completed its second reading. The Bill was, therefore, not rejected on its merits, but rejected for procedural reasons. The Bill was originally introduced by Femke Halsema, a member of parliament for the opposition Green Left party. Halsema left the lower chamber in

\footnotetext{
*Associate Professor, Department of Public Law and Governance, Law School, Tilburg University, The Netherlands.

${ }^{1}$ P.J. Oud, Het constitutioneel recht van het Koninkrijk der Nederlanden II, 8 (Zwolle, 1947).

${ }^{2}$ Mark Tushnet, Advanced Introduction to Comparative Constitutional Law 50 (2d ed. 2018).

${ }^{3}$ See generally Gerhard van der Schyff, Judicial Review of Legislation: A Comparative Study of The United Kingdom, the Netherlands And South Africa 22-33 (2010).

${ }^{4}$ Parliamentary Proceedings II, 2018-19, no. 10, item 8.
} 
2010 and did not experience its lapsing first hand. ${ }^{5}$ For the sake of clarity, this Article will refer to this attempt to amend the Constitution as the Halsema Bill.

One might be forgiven for thinking that the lapsing of the Halsema Bill confirmed the Netherlands on its path toward constitutional exceptionalism. ${ }^{6}$ This would be only partially correct. At roughly the same time the Bill lapsed in 2018, the State Commission on the Parliamentary System published its lengthy report in which it advised the government to introduce the constitutional review of acts of parliament by the judiciary, among an array of other proposals. ${ }^{7}$ The government instituted the State Commission in 2017 with the task of studying whether the country's parliamentary system was "future proof." 8 The Commission's recommendation for reforming Article 120 of the Constitution resembles the Halsema Bill in many respects. Though several differences do exist. In its first reaction to the report, the Cabinet indicated that it needed more time to study the proposals on constitutional review. ${ }^{9}$

The debate on constitutional review by the judiciary in the Netherlands is clearly far from over given the current situation. In addition to national academic interest in the topic, the country's somewhat unique position among its European peers also justifies its study as comparative constitutional law material. Consequently, this Article will critically analyze and evaluate the question of whether the prohibition on constitutional review by the judiciary of acts of parliament should be reformed. The country's exceptionalism in this regard, and by implication its comparative value, will be shown to have little merit given the need to protect and promote the normativity of the Constitution. In making the argument for reform, the structural embeddedness of Article 120 of the Constitution will become apparent. In preventing the case for reform from becoming an empty victory because of this, this Article will also consider the question of how such reform can be achieved. While the debate usually centers on the steps to be taken by the legislature in reforming the provision, this Article will point to the potential role of the courts in effecting constitutional change through legal development.

The analysis is divided into three parts. The first part, Section B, will sketch the context of the prohibition in Article 120 of the Constitution. The range of the prohibition will be considered to get a clear picture of the state of play in Section B.I. Closer attention will then be paid to understanding the various reform proposals. This will include comparing the State Commission and the Halsema Bill against the background of the applicable constitutional amendment procedure in Section B.II. The second part, Section C, will focus on the case for reform by evaluating new arguments and updating others. This means assessing: The impact of the courts' powers of treaty review on the question of constitutional review, in Section C.I; the true value of the doctrine of legislative primacy in settling the issue of reform, in Section C.II; and the consequences of composite constitutional thinking on the debate, in Section C.III. This last consideration is one which usually attracts little attention if any. Yet, the multilevel context of the Constitution is becoming increasingly important to gauge the possible added value of judicial review. In addressing the question of reform, the meaning of the recent Urgenda judgments on climate change will be factored in to better understand the judicial function in the Netherlands. ${ }^{10}$

\footnotetext{
${ }^{5}$ Parliamentary Papers II, 2001-02, 28331, no. 2. Jolanda Sap, Liesbeth van Tongeren, and Kathalijne Buitenweg later each sponsored the Bill.

${ }^{6}$ Dutch exceptionalism still includes the rare practice of appointing mayors by government decree. Previously art. 131 of the Constitution mandated this method, but since 2018, the legislature can freely choose another method such as elections, something which it has not yet done.

${ }^{7}$ State Commission Rep., Democracy and the Rule of Law in Equilibrium: Final Report of the State Commission on the Parliamentary System in the Netherlands, 144-66 (2018). References will be made to the English translation of the State Commission's report, see Lage drempels, hoge dijken, Democratie en rechtsstaat in balans (2018) for the Dutch original.

${ }^{8}$ See Besluit van 1 februari 2017, Stcrt. 2017, 6895 for the decision installing the Commission.

${ }^{9}$ Parliamentary Papers I, 2018-19, 34 430, F, at 4, 20.

${ }^{10}$ Hoge Raad der Nederlanden [HR] [Supreme Court], 20 Dec. 2019, ECLI:NL:HR:2019:2006 (Netherlands/Urgenda) [hereinafter Urgenda III]; Gerechtshof Den Haag [Hof] [Court of Appeal of The Hague], 9 Oct. 2018, ECLI:NL:
} 
The threads of the discussion will be drawn together in Section C.IV in summarizing the case reform, before sketching a roadmap for reform in the third part, Section D.

\section{B. The Context of the Prohibition on Constitutional Review}

\section{The Range of Article 120 of the Constitution}

The Constitution of the Netherlands dates from 1815, while the prohibition on constitutional review was introduced by the revision of 1848 . Before such time, the text was silent on the issue of review. ${ }^{11}$ The provision was included as a way of strengthening the country's fledgling parliamentary democracy, and originally stated that "acts of parliament are inviolable." 12 This wording has been retained across various revisions since, receiving its current formulation in Article 120 after the major revision of 1983. The prohibition now reads: "The constitutionality of acts of parliament and treaties shall not be reviewed by the courts." ${ }^{13}$ In comparison to its previous formulation, the prohibition on constitutional review is now expressly directed at the judiciary and covers not only acts of parliament, but also treaties.

With regard to acts of parliament, Article 120 of the Constitution prevents the courts from judging whether a lower norm, an act, is in accordance with a higher norm, the Constitution. ${ }^{14}$ This restricts the unwritten rule that courts are competent to decide if lower norms of law are in accordance with higher norms. The effect is to establish a strict separation between the legislature, on the one hand, and the courts, on the other hand. The legislature is, by implication, the sole body capable of determining the constitutionality of the acts it passes. ${ }^{15}$ This extends to both the formal and material qualities of acts. ${ }^{16}$ By including only acts of parliament in the prohibition, and not legislation as such, courts remain competent to review the constitutionality of secondary, or delegated, legislation. ${ }^{17}$ Article 120 is not intended to withdraw the Constitution entirely from the courts, however, as they may still interpret acts of parliament in accordance with the Constitution in the event of legislative ambiguity. ${ }^{18}$ In practice, this duty is quite rare and weak, given that the courts are careful not to overstep the distinction between interpreting and reviewing acts of parliament. The contra legem doctrine, first developed by the Supreme Court in the 1970s, might seem like an exception though to the courts' cautious attitude when interpreting the Constitution. The doctrine holds that courts will not apply acts of parliament that occasion harsh consequences for those involved in a

GHDHA:2018:2591 (Netherlands/Urgenda) [hereinafter Urgenda II]; Rechtbank Den Haag [RB] [District Court of The Hague], 24 June 2015, ECLI:NL:RBDHA:2015:7145 (Netherlands/Urgenda) [hereinafter Urgenda I].

${ }^{11}$ Interestingly, art. 99 of the short-lived 1801-05 republican Batavian Constitution included a procedure whereby the three member National Syndicate could bring cases before the National Court concerning public authorities violating the Constitution or acts of parliament.

12“De wetten zijn onschendbaar" (author's translation) (Dutch).

${ }^{13}$ "De rechter treedt niet in de beoordeling van de grondwettigheid van wetten en verdragen" (author's translation) (Dutch). English translations of the Constitution are taken from GovernMENT of THE NETHERLANDS, THE CONSTITUTION OF THE KINGDOM OF THE NETHERLANDS 2008 https://www.government.nl/binaries/government/documents/regulations/2012/10/ 18/the-constitution-of-the-kingdom-of-the-netherlands-2008/the-constitution-of-the-kingdom-of-the-netherlands-2008.pdf.

${ }^{14}$ The Dutch hierarchy of norms reads, in descending order: (i) international law and EU law, (ii) Charter of the Kingdom of the Netherlands, (iii) Constitution of the Netherlands, (iv) acts of parliament, (v) government decrees: orders in council, (vi) government decrees: minor orders in council, (vii) ministerial regulations, (viii) provincial ordinances, (ix) local government ordinances. See M.C. Burkens, H.R.B.M. Kummeling, B.P. Vermeulen \& R.J.G.M. Widdershoven, Beginselen van de DEMOCRATISCHE RECHTSSTAAT: INLEIDING TOT DE GRONDSLAGEN VAN HET NEDERLANDSE STAATS- EN BESTUURSRECHT 91 (8th ed. 2017).

${ }^{15}$ A.W. Heringa, J. van der Velde, L.F.M. Verhey \& W. van der Woude, StaAtsrecht 433 (13th ed. 2018).

${ }^{16}$ See BuRKENS ET AL., supra note 14, at 199-200.

${ }^{17}$ A.J. Nieuwenhuis, M. DEn Heijer \& A.W. Hins, HoofdstukKen grondrechten 54 (4th ed. 2017).

${ }^{18}$ See id. at 53-54; M.L.P. VAN Houten, MEer ZICHT OP WETGEVING: RECHTERLIJKE TOETSING VAN WETGEVING AAN DE GRONDWET EN FUNDAMENTELE RECHTSBEGINSELEN 46-51 (Schoordijk Instituut 1997); G. Boogaard \& J. Uzman, Commentaar op artikel 120 van de Grondwet, in ARTikelsgewijs COMMENTAAR OP DE Grondwet 1, 10 (E.M.H. Hirsch Ballin \& G. Leenknegt eds., 2016) https://www.nederlandrechtsstaat.nl/grondwet/artikel.html?artikel=120 (last visited Aug. 27, 2019). 
contravention of fundamental principles of law. ${ }^{19}$ The doctrine, however, applies only in the event the legislature did not foresee, or intend, the harsh consequences. The effect is not to question the legislature or exempt certain cases from the prohibition on constitutional review, as is sometimes thought. ${ }^{20}$ Instead, the doctrine shows that the courts are careful to fulfill the legislature's will.

Contrary to the wording of Article 120 of the Constitution, the range of national higher law excluded from judicial review is not limited to the Constitution alone. Apart from the Constitution, the Charter of the Kingdom of 1953 is also a norm in the hierarchy, with a higher value than acts of parliament. ${ }^{21}$ Consequently, the Charter ranks higher than the Constitution but comes in just below treaties. The Charter applies to the Kingdom as a whole, which includes not only the Netherlands, but also its other constituent parts in the Caribbean of Curaçao, Aruba, and Sint Maarten. Together with the Netherlands, these countries form the Kingdom, each with their own national authorities and Constitution. Article 120 belongs to the Constitution of the Netherlands, and not to the constitutions of the other countries comprising the Kingdom.

In a landmark judgment from 1989, the Harmonisatiewet case, the Supreme Court ruled that the effect of Article 120 was also to rule out reviewing acts of parliament for compliance with the Charter. ${ }^{22}$ The Court ruled this way even though the Charter does not expressly prohibit its judicial review. In reaching this conclusion, the judgment perceived Article 120 of the Constitution to embody a general cornerstone of constitutional law in the Netherlands applicable to the Charter as well. ${ }^{23}$ In addition, the Court ruled that the prohibition on review included unwritten fundamental principles of law. ${ }^{24}$ The general effect of the judgment was to rule out the judicial review of acts of parliament for compliance with any national sources of higher law, be it the Charter, the Constitution, or fundamental legal principles.

Establishing the range of the prohibition did not preclude the Supreme Court from remarking that the contested act of parliament contradicted legal certainty, which is one of the fundamental legal principles. ${ }^{25}$ The Court's remark could be interpreted as an example of weak judicial review, by noting a legislative failure without sanctioning it as strong review would have it. A practice of weak review by the courts of the Constitution or other national sources of higher law has not developed to date, although a few writers deem the competence to exist because of the remark. ${ }^{26}$ Exempting weak review from Article 120 of the Constitution, however, does not seem to be reflective of orthodox thinking. General commentaries on the provision are usually silent on weak review and, at best, only note the Court's remark. ${ }^{27}$ In the event that weak review is discussed, particular caution is either advised in respect of the judgment or such review is mentioned as

\footnotetext{
${ }^{19}$ Hoge Raad der Nederlanden [HR] [Supreme Court], 14 Apr. 1989, ECLI:NL:PHR:1989:AD5725 (Harmonisatiewet), paras. 3.4, 3.9 [hereinafter Harmonisatiewet].

${ }^{20}$ See Boogaard \& Uzman, supra note 18 , at 10 (characterizing contra legem as an exception to art. 120 of the Constitution). ${ }^{21} I d$.

${ }^{22}$ Harmonisatiewet at para. 4.6.

${ }^{23} \mathrm{Id}$. at paras. $4.2-4.3$.

${ }^{24} I d$. at paras. $3.5-3.6$.

${ }^{25} \mathrm{Id}$. at para. 3.1.

${ }^{26}$ For references and discussion of weak judicial review of the Constitution based on the Supreme Court's remark, see VAN DER SCHYFF, supra note 3, at 191-92; Angelo Rinella, Constitutional Interpretation: The Dutch Case in Comparative Perspective, in The Dutch Constitution Beyond 200 Years: Tradition and Innovation in a Multilevel Legal ORder 169, 182-83 (Giuseppe Franco Ferrari, Reijer Passchier \& Wim Voermans eds., 2018) [hereinafter THE Dutch CONSTITUTION BEYOND 200 YEARs] (“judicial warning” or "expert advice"); Paolo Passaglia, Constitutional Review in the Netherlands: A Few Remarks From an Outsider's Perspective, in The DutCH CONSTITUTION Beyond 200 YeARs, supra, at 273, 289 (unofficial "declaration of incompatibility").

${ }^{27}$ E.g., L. Dragstra, N.S. Efthymiou, A.W. Hins \& R. De Lange, Beginselen van het Nederlandse StaAtsRecht 215-17 (18th ed. 2015); HERINGA ET AL., supra note 15, at 436; BURKENS ET AL., supra note 14, at 204. This stands in contrast to treaty review based on art. 94 of the Constitution (see Section C.I); when conducting such review courts exercise strongform review in principle, although instances of weak review can be found, see JERFI UZMAN, CONSTITUTIONELE REMEDIES BIJ SCHENDING VAN GRONDRECHTEN: OVER EFFECTIVE RECHTSBESCHERMING, RECHTERLIJK ABSTINEREN EN DE DIALOG TUSSEN RECHTER EN WETGEVER 9 (2013).
} 
something that could be introduced. ${ }^{28}$ Given the lack of judicial practice and what can be deduced from general commentaries, the more conventional position seems to be that Article 120 encompasses both the strong and weak review of acts of parliament.

Whereas an express prohibition was necessary to prevent the courts from reviewing the constitutionality of acts of parliament, its extension in Article 120 of the Constitution to treaties was unnecessary. According to the hierarchy of legal norms, treaties stand above the Constitution while acts of parliament rank directly below the Constitution. By extending the reach of the provision to include treaties, Article 120 of the Constitution does not exclude their judicial review as much as it confirms the hierarchy of norms in relation to treaties. This is because the constitutional review of treaties by the courts would have been impossible in any event, given their higher rank in the norm hierarchy. As a matter of fact, acts of parliament, and even the Constitution, may be judicially reviewed against binding international law, given the higher rank of such law in relation to all sources of national law. The relationship between the constitutional and treaty review of acts of parliament will be explored further in Section C.I.

\section{Proposals and Procedure for Reforming Article 120 of the Constitution}

In putting Article 120 of the Constitution further into perspective, attention must be paid to the proposals for its reform and the constitutional amendment procedure. In doing so, the general nature of the proposals will become apparent, thereby laying the basis for discussing the arguments for and against constitutional reform in Section C. Also, the sheer number of proposals taken together with the long timespan of the discussion will show the real executive and legislative reluctance to reform the provision. The structural embeddedness of the provision will be amplified by explaining the difficult procedure to amend the Constitution. These insights will be drawn on in Section D in charting the way forward after having reflected on the merits of reform.

The recommendations of the State Commission and the Halsema Bill are but the most recent examples of initiatives aimed at reforming Article 120 of the Constitution. ${ }^{29}$ Another example to date supporting reform is the Proeve van een nieuwe Grondwet of 1966 . Written at the behest of the Ministry of Home Affairs, the document developed a draft Constitution in order to stimulate discussion about constitutional change in general. In 1969, the Second Report of the then State Commission on the Constitution and the Electoral Law endorsed the Proeve's proposal for amending the prohibition on constitutional review. These reports left the government unconvinced, as the bar was retained during the last major revision of the Constitution in 1983. In 1991, the Cabinet presented its preliminary point of view supporting the introduction of constitutional review, pointing out that the only remaining question concerned the type of review to be introduced. ${ }^{30}$ The attorney general of the Supreme Court, the Council of State, and selected academics were asked about the topic. ${ }^{31}$ The Cabinet, nevertheless, decided not to follow through with the introduction of review, further consulting the Supreme Court in 1997.

The issue was revived again in 2002 by the publication of a Cabinet note cautiously favoring reform in response to an official report on fundamental rights in the digital age. ${ }^{32}$ Just before the Cabinet made its views known, the now lapsed Halsema Bill was tabled in the same year. This was an attempt by some in the parliamentary opposition to keep reform on the agenda if the Cabinet backed down again. ${ }^{33}$ A number of recommendations followed the Bill. In 2006, the governmentconvened National Convention, entrusted with producing ideas on how to narrow the gap

\footnotetext{
${ }^{28}$ Boogaard \& Uzman, supra note 18, at 4-5; BURKENS ET AL., supra note 14, at 203-04.

${ }^{29}$ Parliamentary Papers II, 2002-03, 28, 331, no. 9, at 16-18; Harmonisatiewet at paras. 4-8.

${ }^{30}$ Government Publication, Nota inzake rechterlijke toetsing (1991).

${ }^{31}$ For the advice of the Supreme Court, see 7 NJCM-Bulletin 243 (1992).

${ }^{32}$ Constitutionele toetsing van formele wetten of 22 Apr. 2002, Parliamentary Papers II, 2001-02, 28, 355, no. 2.

${ }^{33}$ Parliamentary Papers II, 2001-02, 28, 331, nos. 1, 2.
} 
between the people and politics, favored reforming the prohibition on review. ${ }^{34}$ Although not formally a part of its remit, the State Commission on the Constitution also joined the chorus in favoring reform in 2010. This was followed by the most recent State Commission, which devoted a substantial section in its 2018 report to argue the case for constitutional review by the judiciary. ${ }^{35}$ In its response to the report, the Cabinet called for more time to study the proposals, noting that the Commission's case for review was not immediately persuasive. ${ }^{36}$ The Cabinet added that it did not rule out counter-proposals, such as allowing weak constitutional review, instead of legally binding judgments. ${ }^{37}$

In addition to not achieving reform, most of the proposals and studies have another feature in common. While the vast majority of proposals endorse reforming Article 120 of the Constitution, they stop short of calling for its abolition. Generally, the proposals favor only the judicial review of classical rights. Acts of parliament that violate such rights would consequently not be applied by the courts. This would leave the prohibition intact regarding socio-economic rights and other constitutional provisions, such as those relating to the organization of the state and legislative procedure. The Halsema Bill, for example, would have introduced a sub-article in Article 120 of the Constitution listing the provisions exempted from the prohibition on review. ${ }^{38}$ The most recent State Commission proposed the same approach. ${ }^{39}$ Where most proposals differ is on the type of review to be introduced. While the Halsema Bill favored decentralized review by allowing all courts to conduct review, the State Commission favors the concentration of review in the hands of a constitutional court to be created for this very purpose. ${ }^{40}$

For a proposal to reform Article 120 of the Constitution, it would have to pass two readings to successfully navigate the long and difficult constitutional amendment procedure. ${ }^{41}$ During the first reading, an amendment bill must be passed by a simple majority in both houses of parliament. A general election for the House of Representatives must precede the second reading, which requires that both houses pass the bill with a two-thirds majority. While the Halsema Bill was tabled in 2002 and passed its first reading in 2008, it never completed its second reading. This was the case even though there had been three general elections after its first reading. As the Halsema Bill passed it first reading in the Senate by only one vote, it seems its supporters were hesitant of a second reading, fearing that the required two-thirds majority would not materialize. This hesitance was not rewarded, as the House of Representatives decided in 2018 that the Halsema Bill had lapsed for not completing its legislative trajectory sooner. ${ }^{42}$ Even the Member of Parliament who sponsored the Halsema Bill tried to withdraw it, citing that it had become unattainable. ${ }^{43}$ The most important attempt at reforming the prohibition on review since

\footnotetext{
${ }^{34}$ J.W. SAP ET AL., HaRT VOOR DE PUblieke ZAAK. AANBEVELINGEN VAN DE NATIONALE CONVENTIE VOOR DE $21 \mathrm{E}$ EEUW 45-46 (2006).

${ }^{35}$ Rapport Staatscommissie Grondwet 46-47 (2010); State Commission Rep., supra note 7, at 144-59.

${ }^{36}$ Parliamentary Papers I, 2018-19, 34 430, F, at 4, 20.

${ }^{37} I$ d.

${ }^{38}$ Typical classic rights in chapter 1 (bill of rights) were earmarked for exemption, as well as some other provisions in the Constitution that arguably also guarantee such rights, for example, the prohibition on capital punishment in art. 114 .

${ }^{39}$ State Commission Rep., supra note 7, at 149-50.

${ }^{40} I d$. at 214-15; Parliamentary Papers II, 2002-03, 28 331, no. 9, at 16-18. See also Gerhard van der Schyff, Structuring the Judiciary to Conduct Constitutional Review in the Netherlands: A Comparative and European Perspective, 14 EUR. J. L. REFORM 467 (2012).

${ }^{41} \mathrm{Gw}$. [Constitution] art. 137. When amending the Constitution, the legislature (wetgever) is known as the constitutional legislature (grondwetgever).

${ }^{42}$ Parliamentary Proceedings II, 2018-19, no. 10, item 8; Parliamentary Papers II, 2018-19, 28 331, no. 13. By identifying "special circumstances" the House could have finished the second reading. On the lapsing of constitutional amendment bills, see Eva van Vugt, Ruim, redelijk of rigide: De uitleg van artikel 137, vierde lid Grondwet door de Raad van State, 10 TIJDSCHRIFT VOOR CONSTITUTIONEEL RECHT 51 (2019).

${ }^{43}$ Parliamentary Papers II, 2018-19, 28 331, no. 12. Withdrawing a constitutional amendment in second reading is procedurally impossible. Such bills can be only voted on or lapse.
} 
its debut in 1848 had fallen victim to a slow and quiet demise. Political reluctance by some in the legislature, and a mixture of disinterest and opposition by others, sealed the Halsema Bill's fate. Even relaxing the constitutional amendment procedure, as proposed by the State Commission, would not have come to the Halsema Bill's rescue, given its general lack of support. ${ }^{44}$

What becomes apparent in considering the various attempts at reform is that the weight of official reports and studies has consistently come down on the side of at least softening the prohibition on review in Article 120 of the Constitution. By contrast, the political institutions have, at best, been lukewarm about the idea. Their opposition seems to be rooted in doubts about the relationship between constitutional review, on the one hand, and treaty review and legislative primacy, on the other hand. These issues will be discussed below in appraising the merits of reform in addition to insights from composite constitutionalism.

\section{The Case for Constitutional Reform}

\section{Treaty Review by the Courts of Acts of Parliament}

The constitutional system of the Netherlands accords an important place to international law, operating on the monist principle that its legal order comprises both national and international law. ${ }^{45}$ A consequence of its monist system is that courts can review the compatibility of national legal norms, including acts of parliament, with international law, which is of a superior rank in the hierarchy of norms. ${ }^{46}$ Article 94 of the Constitution is very important in this regard, as it outlines the conditions under which treaty review can be carried out. ${ }^{47}$ This provision, whose forerunner was included by the constitutional revision of 1953, enjoins the courts to give preference to international law over conflicting national law if an international provision is sufficiently clear for judicial application and the provision was intended to create rights for individuals. ${ }^{48}$ International legal provisions aimed at only creating reciprocal obligations between states fall outside the purview of the courts. In practice, the courts have come to apply typical classical rights, especially from the European Convention on Human Rights (ECHR), instead of socio-economic rights. ${ }^{49}$ Socio-economic rights are often considered too vague for direct application or intended to create only interstate obligations instead of subjective rights.

Treaty review creates the contradictory situation that while courts may not review the constitutionality of an act of parliament, the act in question can be reviewed against international law. This raises questions about the relationship between the two types of review and what this means for maintaining the prohibition on constitutional review. These questions are addressed below.

\section{Comparing National and International Guarantees}

The argument could be made that constitutional review is superfluous to the extent that it copies treaty review. In such a situation, constitutional review does not add anything meaningful to the existing powers of the courts, but simply doubles existing protection. When comparing the two

\footnotetext{
${ }^{44}$ The State Commission proposed that all second readings be conducted in a joint session of both chambers, thereby preventing a small minority in the Senate from blocking an amendment bill, as is currently possible. See State Commission Rep., supra note 7, at 214, 231. The cabinet supported the proposal, see Parliamentary Papers I, 2018-19, 34 430, F, at 4, 5, $16-17$. But the difficult constitutional amendment procedure complained of would itself probably have prevented this reform.

${ }^{45}$ See Jerfi Uzman, Changing Tides: The Rise (and Fall?) of Judicial Constitutional Review in the Netherlands, in THE DUTCH CONSTITUTION BEYOND 200 YEARS, supra note 26, at 257, 263-65.

${ }^{46}$ See The Constitution of the Kingdom of the Netherlands 2008, supra note 14 for the hierarchy of norms.

${ }^{47} \mathrm{Gw}$. [Constitution] art. 94 ("Statutory regulations in force within the Kingdom shall not be applicable if such application is in conflict with provisions of treaties or of resolutions by international institutions that are binding on all persons."). See also State Commission Rep., supra note 7, at 151 (explaining that treaty review was intended to avoid conflict with international law as much as possible, in particular because of other countries' interests).

${ }^{48}$ See also BURKENS ET AL., supra note 14 , at 359-60.

${ }^{49} I d$. at 362 .
} 
types of review, it becomes clear that constitutional review would not amount to a carbon copy of treaty review. As a consequence, the mere existence of treaty review does not disqualify the case for constitutional review.

Apart from provisions dealing with the organization of the state and the separation of powers in the Constitution, the protection of its fundamental rights differs as to its range and formulation from many rights in international law. The right to education in Article 23 of the Constitution is quite a different read than the corresponding right in Article 2 of the First Protocol to the ECHR, for instance. While the national right is very detailed, given its eight sub-articles, the international right is more focused on outlining principles that can be applied to a host of jurisdictions in addition to national guarantees.

Turning to the nature of protection, the State Commission, in its report, made clear that the crux of the Constitution's protection is formal. ${ }^{50}$ Fundamental rights in the Constitution may be limited, to the extent that they can be, only by an act of parliament or through delegated legislation if so allowed by the Constitution. The right to freedom of religion in the first paragraph of Article 6 of the Constitution may be limited only by an act of parliament. At the same time, the second paragraph also allows limitations by delegated legislation in the instances described there. By contrast, a limitation of the corresponding right in Article 9 of the ECHR needs only to be based on a domestic legal rule, leaving the type of rule up to the discretion of the national authorities. The constitutional requirements regulating the legality of a limitation are clearly stricter than those in most treaties. In addition, the second paragraph of Article 9 of the ECHR requires that a limitation must be necessary for a democratic society, thereby introducing a proportionality test. The Constitution, given its emphasis on the legality of interferences, does not include a comparable interference legitimacy test. In the event that judicial review is introduced, courts could read in such a test. It remains far from certain though that they would simply copy the tests in some treaties. ${ }^{51}$

\section{Minimum Level of Protection Surpassed}

Another reason for constitutional review not to follow from treaty review would be if the two types of review provided different levels of protection. This would be the case if treaty review provided a minimum level of protection in the national order, as opposed to a higher level provided by constitutional review. The Halsema Bill and a previous State Commission, for instance, took the view that international law amounts only to the minimum protection of fundamental rights. ${ }^{52}$ In the event that this is true, it could be argued that allowing the courts to review the Constitution would amount to a much greater breach of the separation of powers than under treaty review. Consequently, a more serious justification of constitutional review would be required, as opposed to treaty review, which impairs the separation of powers less by providing only a minimum level of protection.

By many accounts however, modern international law amounts to much more than simply the lowest common denominator in protecting fundamental rights. The criticism leveled at the European Court of Human Rights (ECtHR) by Marc Bossuyt, former president of the Constitutional Court of Belgium, proves the point. Bossuyt has argued that the ECtHR overreaches itself, especially in asylum cases, by acting as a court of the fourth instance instead of maintaining a proper distance from national authorities. ${ }^{53} \mathrm{He}$ has not been alone in his criticism as an intervention by Lord Hoffmann shows. ${ }^{54}$ Whether one agrees with these criticisms or not, they illustrate that the ECHR does not necessarily match the view of it being a minimum standard.

\footnotetext{
${ }^{50}$ State Commission Rep., supra note 7, at 154.

${ }^{51}$ It seems more likely that courts will draw inspiration from the material test proposed by the previous State Commission, which included a provision protecting the "core" of fundamental rights. See Rapport Staatscommissie Grondwet, supra note 35, at 56.

${ }^{52}$ Parliamentary Papers II, 2002-03, 28 331, no. 9, at 12; Rapport Staatscommissie Grondwet, supra note 35, at 24.

${ }^{53}$ Marc Bossuyt, The Court of Strasbourg Acting as an Asylum Court, 8 Eur. Const. L.Rev. 203, 215-16 (2012).

${ }^{54}$ Lord Hoffmann, The Universality of Human Rights, Judicial Studies Board Annual Lecture, at para. 27 (Mar. 19, 2009).
} 
In the case of the Netherlands, it is undeniable that treaty review has become a firm feature of securing legal protection for individual and private interests. The ECHR can even be said to be the country's veritable bill of rights as it has shaped its legal landscape for decades, together with other treaties. ${ }^{55}$ This is amplified by the fact that although the ECHR guarantees only classical rights, the ECtHR interprets some rights as possessing a clear social dimension well beyond what would be necessary to establish minimum benchmarks for the operation of political systems. ${ }^{56}$ The potential impact of this on the national protection of rights is strikingly clear from the Urgenda case on preventing climate change. In 2019, the Supreme Court confirmed the 2018 Court of Appeal in The Hague decision, which, on its part, confirmed that city's 2015 District Court decision. The District Court decision provided that the state had to act immediately to reduce the emission of greenhouse gasses by twenty-five percent by the end of 2020, relative to 1990 levels. ${ }^{57}$ The Supreme Court and Court of Appeal based this decision on the right to life in Article 2 of the ECHR and the right to respect for private and family life in Article 8 of the ECHR. These Courts made it clear that such rights not only extend to environmental situations but also occasion positive obligations for the state to act in ensuring their sufficient protection. ${ }^{58}$ As the state had failed in its duty to protect these rights, it violated them..$^{59}$ Moreover, the Courts were left unconvinced by the state's argument that imposing a duty on it to act would breach the separation of powers by allowing judges to enter the political domain, or that it would impinge on the state's margin of appreciation. ${ }^{60}$ It was explained that the margin applied only to the measures chosen by the state in meeting its obligations under the ECHR, and not to the fact that it had to meet those obligations. The message from the Supreme Court and the Court of Appeal in The Hague is clear. Treaty review cannot, as a matter of course, be equated with the application of narrowly defined classical rights to clear-cut situations. Instead, it has the potential to encompass much more. If the courts are entrusted with power of such capacity, it would be illogical to continue their exclusion from constitutional review.

\section{Primacy of the Legislature and the Role of the Courts}

Treaty review in the Netherlands affirms the proposition by Dawn Oliver and Carlo Fusaro that a country's membership of a supranational legal order, such as the ECHR, can act as a major agent for constitutional change influencing topics such as the role of the judiciary. ${ }^{61}$ As both the State Commission and the Halsema Bill show, treaty review brought an end to the strict separation of powers between the legislature and the courts. ${ }^{62}$ The consequence is to cast serious doubt on the doctrine of the primacy of the legislature as the politico-constitutional mainstay of the case against constitutional review. Holding that legislators, as opposed to appointed judges, should decide constitutional issues because of their democratic credentials, becomes an academic exercise given the everyday reality of treaty review. ${ }^{63}$

Even if there had been no theoretical spill-over from treaty review breaching the walls of the primacy of the legislature, there would still be reason to reject an exclusive alignment of

\footnotetext{
${ }^{55}$ See BURKENS ET AL., supra note 14, at 358-59 (appraising the influence of treaty review); Uzman, supra note 45, at 265-69. See also the critical notes by Barbara Oomen, Rights for Others: The Slow Home-Coming of Human Rights in the NETHERLANDS (2014).

${ }^{56}$ E.g., Sidabras and Džiautas v. Lithuania, App. Nos. 55480/00 \& 59330/00, para. 47 (Jul. 27 2004), http://hudoc.echr.coe. int/fre? $\mathrm{i}=001-23517$ (paying attention to the European Social Charter and its interpretation by the European Committee of Social Rights).

${ }^{57}$ Urgenda III at para. 9; Urgenda II at para. 76.

${ }^{58}$ Urgenda III at paras. 5.2.2-5.3.4, 5.6.1-5.6.4; Urgenda II at paras. 40-43, 45, 73, 76.

${ }^{59}$ Urgenda II at para. 67.

${ }^{60}$ Urgenda III at para. 5.3.2, 8.3.1-8.3.5; Urgenda II at paras. $67,74$.

${ }^{61}$ How Constitutions Change: A Comparative Study 409 (Dawn Oliver \& Carlo Fusaro eds., 2011).

${ }^{62}$ State Commission Rep., supra note 7, at 147; Parliamentary Papers II, 2002-03, 28 331, no. 9, at 5, 11.

${ }^{63}$ See the comparable point in Rapport Staatscommissie Grondwet, supra note 35, at 47.
} 
constitutional review with legislative review as it occurs in Article 120 of the Constitution. As it is argued below, the prohibition can also be criticized on its own merits.

\section{Centrality of Acts of Parliament}

According to the primacy of the legislature, acts of parliament are the preferred tools with which to protect the Constitution. As explained above, Article 120 of the Constitution expressly exempts acts of parliament from judicial review. The centrality of acts of parliament is further confirmed by the fact that limitations to fundamental rights must be based on acts, as pointed out when treaty review was compared to constitutional review in Section C.I.1.

There is a profound cause to question the extent of the reliance placed on acts of parliament in protecting the Constitution. This is because the Netherlands has by no means been exempted from the inflation to which acts of parliament have been subjected in other jurisdictions. The country is a clear example of what Mauro Cappelletti termed the "administrative state" in describing the large number of issues regulated through delegated legislation. ${ }^{64}$ The Council of State, the government's highest advisory organ, has on numerous occasions referred to, and warned against, the hollowing out of acts of parliament. ${ }^{65}$ The State Commission noted this trend in 2018, and before it the Halsema Bill in 2002. ${ }^{66}$ The new Environment and Planning Act serves as an example. ${ }^{67}$ The Act, which comes into force in 2021, merges twenty-six acts of parliament into one new Act. The Act is essentially a legislative framework, the workings and content of which will have to be fleshed out by government decrees. Its effect is to put the importance of acts into perspective, and by implication, the doctrine of the primacy of the legislature on which it rests.

Such legislative frameworks serve not only to empower other rule-makers, such as the government, but also the courts. This is because the courts in the Netherlands can review the constitutionality of delegated legislation, as long as they refrain from reviewing the acts of parliament from which such delegated powers issue. The wider the delegated mandate granted in the act of parliament, the wider the commensurate powers of judicial review, and the weaker the doctrine of primacy as a constitutional norm. To this, it may also be added that even if the practice of delegation would decrease, indeterminate norms in acts of parliament would still require judicial interpretation and application, thereby exposing the limits of legislative primacy further. The judgment by the District Court in the Urgenda case serves as a pertinent example of the courts' power to interpret such open norms. ${ }^{68}$ While the Supreme Court and Court of Appeal favored treaty review in testing the government's climate policy directly against Articles 2 and 8 of the ECHR, the District Court based its decision on Article 6:162 of the Civil Code, which regulates unlawful action. The latter Court noted that it would factor in the state's obligations when interpreting and applying such private "national-law open standards and concepts, including social proprietary, reasonableness and propriety, the general interest or certain legal principles." 69 In applying the Civil Code, the Court duly turned to the Constitution, the ECHR, and other sources of international law and EU law for inspiration in finding that the government acted unlawfully and had to reduce national greenhouse gas emissions. ${ }^{70}$

\footnotetext{
${ }^{64}$ Mauro Cappelletti, The Judicial Process in Comparative Perspective 14 (1989).

${ }^{65}$ See Annual Report of the Council of State (2018) at 20, 23; Annual Report of the Council of State (2011) at 58-59; Annual Report of the Council of State (2006) at 41, 57; Annual Report of the Council of State (1999) at 49-50; the report commissioned by the Council of State by R.A.J. van Gestel \& A. Vleugel, Herijking van het primaat van de wetgever: De betekenis van kaderwetgeving en delegatie (2013).

${ }^{66}$ Parliamentary Papers II, 2002-03, 28 331, no. 9, at 12-13; State Commission Rep., supra note 7, at 149.

${ }^{67}$ See also State Commission Rep., supra note 7, at 149.

${ }^{68}$ Urgenda $I$.

${ }^{69} \mathrm{Id}$. at paras. 4.43, 4.46. This quotation is taken from the English version of the judgment, published on https://www. rechtspraak.nl/Bekende-rechtszaken/klimaatzaak-urgenda (last visited Aug. 27, 2019).

${ }^{70} I d$. at paras. $4.43,4.46,4.52,4.73,4.93,5.1$.
} 
Acts of parliament may be central to the constitutional edifice of the Netherlands, but they are not as important or self-sufficient in this function as the doctrine of legislative primacy might suggest. Given the reality of the situation, insisting that acts of parliament be insulated from judicial review because of their special role fails to be convincing. The effect is also to question the relevance of constitutional theory that focuses solely on acts of parliament in making the case against judicial review, such as Jeremy Waldron's "core case" against review. ${ }^{71}$ An exclusive focus on acts of parliament in settling the question of judicial review is too narrow, as it overvalues such acts while underestimating the complexity of constitutional checks and balances. ${ }^{72}$ It should also be noted that Waldron's arguments are leveled only at strong-form judicial review of acts of parliament. In contrast, orthodoxy implies that Article 120 of the Constitution excludes both strong and weak review. ${ }^{73}$ If accepted, Waldron's position would only save the provision in part. This leaves the much more difficult case of rejecting weak-form review, too. The idea of weak review has received wide practical and theoretical acceptance across a number of jurisdictions that have been skeptical of judicial review. ${ }^{74}$ This is, in part, because the primacy or supremacy of the legislature is not upset, as courts are denied the final word, especially on the application or validity of acts of parliament. ${ }^{75}$ This type of review has also gained acceptance in political constitutionalist theory as a way of drawing attention to voices of "unpopular or isolated minority groups without access to the democratic sphere."76 At the very least, courts in the Netherlands could put constitutional rights to the same use in reviewing acts of parliament. Admittedly, political constitutionalist thinking views rights as political constructs, as opposed to their entrenched and higher law character in the Dutch Constitution. ${ }^{77}$ But if the problem in both contexts is the same, weak review as the solution could arguably be put to the test in both, too.

If anything, a conflation of constitutional review with legislative review as absolute as Article 120 of the Constitution would have it is open to real challenge. This challenge should not be taken to mean that the centrality of acts of parliament in the Netherlands is to be undone. This has never been the context of the proposals for reforming Article 120. Rather, the focus has always been to introduce a measure of bi-polarity, to use Tim Koopmans' description, to the primacy of the legislature by allowing the courts to review its acts of parliament. ${ }^{78}$ For example, the Halsema Bill made it very clear that its intention was never to supplant legislative democracy but to complement and

\footnotetext{
${ }^{71}$ Jeremy Waldron, The Core of the Case Against Judicial Review Waldron, 115 YALE L.J. 1346, 1353-54 (2006) (referring to "primary legislation enacted by the elected legislature of a polity" as being his concern, and not "judicial review of executive action or administrative decisionmaking").

${ }^{72}$ Consider Pierre Rosanvallon, Counter-Democracy: Politics in an Age of Distrust 8 (2008), whose concept of "counter-democracy" captures a wide range of functions that reinforce electoral democracy.

${ }^{73}$ Waldron, supra note 71, at 1346. Contra Tom Hickey, The Republican Core of the Case for Judicial Review, 17 INT'L J. CONST. L. 288 (2019) (arguing that strong-form judicial review is not necessarily to be discounted). See also Section B.II.

${ }^{74}$ See generally Stephen Gardbaum, The New Commonwealth Model of Constitutionalism: Theory and Practice (2013).

${ }^{75}$ See Human Rights Act 1998, $₫ 3(2)$ (b) (U.K.) (providing that the duty in $\$ 3(1)$ to interpret primary and subordinate legislation in a manner compatible with the incorporated ECHR rights, "does not affect the validity, continuing operation or enforcement of any incompatible primary legislation”); See also Human Rights Act 1998, §2(c) (U.K.) (stating subordinate legislation is unaffected as well, "if primary legislation prevents the removal of the incompatibility").

${ }^{76}$ See Richard Bellamy, Democracy as Public Law: The Case of Constitutional Rights, 14 German L.J. 1017, 1036-37 (2013) (referencing the Human Rights Act 1998 in particular) [hereinafter Bellamy, Democracy as Public Law]; See also Richard Bellamy, The Republican Core of the Case for Judicial Review: A Reply to Tom Hickey. Why Political Constitutionalism Requires Equality of Power and Weak Review, 17 INT'L J. ConsT. L. 317 (2019) [hereinafter Bellamy, The Republican Core of the Case for Judicial Review].

${ }^{77}$ On the nature of rights in political constitutionalist theory in this regard, see Bellamy, Democracy as Public Law, supra note 76, at 1036-37 (mentioning that the Human Rights Act 1998 is "an ordinary piece of legislation"); Bellamy, The Republican Core of the Case for Judicial Review, supra note 76, at 318.

${ }^{78}$ On bipolar constitutionalism, see Tim Koopmans, Courts and Political Institutions: A Comparative View 247-51 (2003).
} 
augment it. ${ }^{79}$ The judiciary is to fulfill an editorial function of sorts by providing a forum for the constitutional contestation of acts of parliament, while the legislature is still to author acts in a primary sense. ${ }^{80}$ This way, the primacy of the legislature remains the default position. The Bill even took the view that judicial review would have to be increasingly circumspect the more the legislature expressed itself on a topic. ${ }^{81}$ Moreover, both the State Commission and the Halsema Bill favor only the ex post review of acts of parliament, as opposed to also the ex ante review of bills. ${ }^{82}$ The effect is to soften the strict separation of powers in Article 120 by introducing review while stopping short of allowing the courts a role at the very heart of the democratic process of law-making. In addition, both the State Commission and the Halsema Bill limit their support to the review of classical rights, thereby leaving the doctrine of primacy untouched as regards socio-economic rights and other constitutional provisions.

The centrality of acts of parliament is neither threatened, nor made controversial by the proposals for reforming Article 120 of the Constitution. But what is controversial to an unacceptable degree is basing Article 120 of the Constitution on their centrality.

\section{Legislative Procedure as Quality}

Acts of parliament can also be scrutinized from a different angle than their central role in the constitutional edifice. This is because the heavy legislative procedure in adopting an act of parliament is, in itself, seen as a guarantee in protecting the Constitution, especially in comparison to the lighter procedures for delegated legislation. ${ }^{83}$ This heavy procedure is amplified by the fact that the Netherlands has a bicameral legislature, thereby supporting the principle of limited government by restricting the process of legislative decision-making. ${ }^{84}$ Although many other unitary states abolished bicameralism in favor of unicameralism, such as in Scandinavia, the Netherlands did not follow this trend. Both legislative chambers have to adopt a bill before it can become law, after having considered the non-binding comments of the Council of State regarding the quality of the proposed legislation. ${ }^{85}$

There is definitely mileage in the view that acts of parliament are to be respected because of the way in which they are made, especially in a bicameral setting. Doubts arise though when such thinking is used to justify Article 120 of the Constitution. This is because acts of parliament are not necessarily constitutional because of their procedural origins. Legislative procedure by itself seems a poor guarantee against a political majority advancing its interests alone in dealing with the Constitution. ${ }^{86}$ In addition, legislative review is by definition ex ante, and thus abstract in nature, which means it cannot discount all ex post issues of constitutionality arising from the application of acts of parliaments. ${ }^{87}$ Ex ante review is also not synonymous with the constitutional scrutiny of bills, as the Constitution does not feature as much here as might be expected. The situation has improved on the past, however, when the lack of policy in this field was lamented and fundamental rights in the Constitution were referred to only on an incidental basis. ${ }^{88}$ Nonetheless, as recently as 2013, Ernst M.H. Hirsch Ballin could still point to a worrying

\footnotetext{
${ }^{79}$ Parliamentary Papers II, 2002-03, 28 331, no. 9, at 14. See also Maurice Adams \& Gerhard van der Schyff, Constitutional Review by the Judiciary in the Netherlands. A Matter of Politics, Democracy or Compensating Strategy?, 66 ZAÖRV 399, 413 (2006).

${ }^{80}$ See Philip Pettit, Democracy, Electoral and Contestatory 42 Nomos 105, 116-18, 132-33 (2000).

${ }^{81}$ Parliamentary Papers II, 2002-03, 28 331, no. 9, at 14.

${ }^{82}$ State Commission Rep., supra note 7, at 158; Parliamentary Papers II, 2002-03, 28 331, no. 9, at 2.

${ }^{83}$ See Parliamentary Papers II, 2002-03, 28 331, no. 9, at 5.

${ }^{84}$ Pettit, supra note 80 , at $128-29$ (referencing bicameralism in the context of limited government).

${ }^{85} \mathrm{Gw}$. [Constitution] art. 73(1).

${ }^{86}$ Pettit, supra note 80 , at $125-26$ (making the point in respect of understanding democracy as nothing more than the sum of electoral institutions).

${ }^{87}$ Parliamentary Papers II, 2002-03, 28 331, no. 9, at 13; State Commission Rep., supra note 7, at 148.

${ }^{88}$ L.F.M. Verhey, Het grondwettelijk beperkingssysteem: Handhaving of herbezinning?, NJCM-Bulletin 216, 230-31 (2003).
} 
"constitutional silence" in many legislative debates. ${ }^{89}$ The State Commission also noted a decline in the overall quality of legislation in its Report in $2018 .^{90}$

Hirsch Ballin attributes the lack of interest in the Constitution, in part, to the fact that treaties can be reviewed by the courts while the Constitution cannot. ${ }^{91}$ This reading seems to be confirmed by the legislative review leading up to the enactment in 2018 of the much-discussed partial prohibition on face-coverings, the so-called burqa ban. ${ }^{92}$ In its explanatory memorandum to the Bill, the government focused nearly exclusively on the ECHR and its jurisprudence. The same applies to the Council of State's opinion. ${ }^{93}$ The Constitution warranted only a few incidental references, such as explaining that the prohibition on the right to freedom of religion would be in the form of an act of parliament as required by Article 6(1) ${ }^{94}$ In discussing the Bill, there was clearly no independent constitutional culture to speak of when compared to the ECHR, which is backed up by the judgments of the ECtHR. Given there is room for improvement, it can be agreed with the Cabinet that the proposals by the State Commission to better constitutional review in the legislative process are to be welcomed. ${ }^{95}$ The State Commission wisely did not propose to strengthen legislative constitutional review as an alternative to judicial review, but instead as an addition to its judicial proposals.

Ironically, the lack of sufficient constitutional debate in the legislature is exemplified by the controversial dismissal by the House of Representatives of the Halsema Bill. Instead of welcoming debate on the possible role of the judiciary in protecting the Constitution and reflecting on its own role in the legislative process, the House dismissed the Bill on a point of procedure. ${ }^{96}$ Criticism can also be leveled at the Senate. Given its indirect election, the Senate is viewed as the preferred chamber to conduct constitutional review, as opposed to the directly elected House as the setting for political choices and majoritarian priorities. ${ }^{97}$ The Senate though, is not always the chambre de réflexion many would want it to be. One of the reasons for this is because Senators have a four-year term, as opposed to the six-year term they had before 1983. The effect is to place them much closer to the election cycle and the political pressure of being re-elected. This may not be as conducive to the ideal of detached review. While the State Commission was not in favor of it, the Cabinet in 2019 unexpectedly announced its support to return to six-year terms. ${ }^{98}$ This time agreeing with the State Commission, the Cabinet also favored allowing the Senate to amend and return bills to the House for its reconsideration. ${ }^{99}$ At present, the Senate can only accept or reject bills. While these reforms are to be supported, it remains to be seen if the Constitution will be amended to allow them, and what will become of them in practice.

By definition, the Senate remains susceptible to political pressure. That is the constant reality. The weaker a governing coalition is, the more vulnerable its senators are to criticism that they are

\footnotetext{
${ }^{89}$ Ernst M.H. Hirsch Ballin, De Grondwet in POlitiek en SAmEnleving: RechtsstaAtlezing 2013, 9-12 (2013). See also Verhey, supra note 88, at 231.

${ }^{90}$ State Commission Rep., supra note 7 , at 149.

${ }^{91}$ Hirsch Ballin, supra note 89, at 13. See also Verhey, supra note 88, at 231.

${ }^{92}$ The act of parliament was adopted on June 27, 2018, and took effect on August 1, 2019. It prohibits face-coverings in a number of spaces, including public transport and government buildings.

${ }^{93}$ Parliamentary Papers II, 2015-16, 34 349, no. 3.

${ }^{94}$ Id. at 7-10; Parliamentary Papers II, 2015-16, 34 349, no. 4, at 8-9.

${ }^{95}$ State Commission Rep., supra note 7, at 157-58. The State Commission advised that improvements to legislative constitutional review be made during the departmental phase and in conducting internet consultations on bills-noting that the Council of State could respond to the issues raised by such consultation. The cabinet agreed to increase the use of internet consultations, and noted that the proposal related to the departmental phase was already standard practice, see Parliamentary Papers I, 2018-19, 34 430, F, at 15-16.

${ }^{96}$ Parliamentary Proceedings II, 2018-19, no. 10, item 8.

${ }^{97}$ See BURKENS ET AL., supra note 14 , at $244-45$ on the role of the Senate.

${ }^{98}$ Compare Parliamentary Papers I, 2018-19, 34 430, F, at 5, 16, with State Commission Rep., supra note 7, at 226-28.

${ }^{99}$ The State Commission expected that this competence would be put to use improving bills' constitutionality (rechtsstatelijkheid). See State Commission Rep., supra note 7, at 220-24. The cabinet indicated that it needed more time to study the proposal. See Parliamentary Papers I, 2018-19, 34 430, F, at 5-6, 22.
} 
more interested in supporting government policy than exercising constitutional review. Consider the situation where the third coalition of Prime Minister Mark Rutte had but a one-seat majority in both houses of the legislature until losing its majority in $2019 .{ }^{100}$ Under such circumstances, it becomes very difficult for senators to be politically detached in matters that might be determinative for the survival of the government. Alternatively, a large government majority in the Senate could encourage complacency among its members. Conversely, the absence of a majority might embolden the opposition to thwart the government's legislative agenda, instead of putting constitutional review first. For example, the 2019 elections saw Forum for Democracy, an opposition party and newcomer to the Senate, attain joint-share of first place in that chamber by garnering twelve seats out of seventy-five. ${ }^{101}$ By comparison, the party holds only two out of the one hundred and fifty seats in the House of Representatives, and so has little leverage in the lower chamber. This has led the party to state that it wishes to use its large block of votes in the Senate to force political change via the upper chamber. ${ }^{102}$

Taking a critical view of the Senate as constitutional guardian does not mean that the institution fails as such in its duty. Various examples illustrate that the chamber can be quite protective of fundamental rights at times. ${ }^{103}$ It can, therefore, be agreed with the State Commission and the Cabinet that the institution has a valuable role to play in protecting the country's democratic rechtsstaat. ${ }^{104}$ The point is, rather, that legislative procedure, as it applies in both the House of Representatives and the Senate, cannot serve as a reason to exclude judicial checks on the constitutionality of acts of parliament as a matter of course. Legislative procedure is inherently too party political and unpredictable for this to be the case.

\section{Composite Constitutionalism as Paradigm}

A multilevel perspective, understood in its international and European Union (EU) dimensions, has largely been lacking from the debate in the Netherlands on constitutional review. This is different from the treaty argument, which concerns itself with distinguishing between treaty review and constitutional review. It is also different from the prohibition in Article 120 of the Constitution preventing the courts from reviewing the constitutionality of treaties. Instead, the focus in this section falls on the normative implications of the Constitution on international and EU law, if acts of parliament were to be reviewed by the courts.

In considering both the State Commission's report and the Halsema Bill, the context of their proposals is largely a domestic or statist one. This is especially true of the Halsema Bill. A statist perspective understands the question of review as one of staatsrecht, the law of the state, as opposed to one of constitutioneel recht, or constitutional law. As Neil Walker explains, replacing "state" with "constitution" is not replacing like with like. ${ }^{105}$ The effect is to replace the concept of

\footnotetext{
${ }^{100}$ The coalition lost its majority in the Senate because of an election, and in the House of Representatives due to a member of parliament having the whip removed by one of the coalition. This has not meant the collapse of the coalition, but it has made the coalition very dependent on the opposition parties for political support. This is no exception anymore, the State Commission noted the current reality of governing coalitions having slim majorities. see State Commission Rep., supra note 7, at 227.

${ }^{101}$ Three senators have since left the party.

${ }^{102}$ See ForUM VOOR DEMOCRATIE, https://forumvoordemocratie.nl/eerste-kamer (last visited Aug. 27, 2019).

${ }^{103}$ For example, in 2011, partly on the basis of privacy concerns, the Senate unanimously rejected Parliamentary Proceedings I, 2010-11, no. 23/4, at 4-6, a government bill, Parliamentary Papers I, 2008-09, 31 466, A, on compulsory participation in a national electronic database regulating patients' medical information. Though in 2012 the protection of the right to freedom of religion was preferred, Parliamentary Proceedings I, 2011-12, no. 33, item 5, at 25-26, over a private member's bill, Parliamentary Papers I, 2010-11,31, 571, A, which intended to prohibit the slaughter of animals without prior stunning in the interest of animal welfare. Noteworthy is that a comparable bill has been tabled, Parliamentary Papers II, 2017-18, 34 908, no. 2, and is making its way through parliament, raising questions about its reception in the Senate.

${ }^{104}$ State Commission Rep., supra note 7, at 219; Parliamentary Papers I, 2018-19, 34 430, F, at 5-6, 16.

${ }^{105}$ Neil Walker, Multilevel Constitutionalism: Looking Beyond the German Debate 3 (LSE “Europe in Question” Discussion Paper Series, LEQS Paper no. 08/2009, 2009).
} 
the state as a regulatory category, which implies "singularity and mutual exclusivity of public authority," with a "universalizing category" suggestive of "continuity and complementarity of public authority." " 106 Public authority is thereby given a post-national and multilevel dimension, as it is recognized that the state alone cannot meet the demands of its inhabitants. ${ }^{107}$ Emphasizing constitutioneel recht, and not staatsrecht, as the appropriate paradigm in regulating and controlling public authority also conditions the question of judicial review and the Constitution. In this regard, it raises questions about the relationship between national, international, and EU legal norms as part of the country's composite constitutional order.

\section{International Dimension}

A constitutional paradigm, as opposed to a statist one, best captures the reality of the monist application of international law in the Netherlands as a method with which to control public power. Within this composite paradigm, treaty review in accordance with Article 94 of the Constitution has led to the legislative process factoring in international law. ${ }^{108}$ This stands in stark contrast to the summary treatment of the Constitution, which suffers from a normative deficit in this regard given Article 120. In addressing this imbalance, the judicial review of acts of parliament against the Constitution could serve to enhance thinking about it and its presence in the country's political life. What is often overlooked is that bolstering the normativity of the Constitution in this way could also serve to increase its role in relation to international law.

Once the prohibition on judicial review in Article 120 of the Constitution is qualified, the argument could be made that acts of parliament approving treaties may be reviewed in principle as well. Strictly speaking, this would not contravene the prohibition in Article 120 on reviewing the constitutionality of treaties, as the object of review would be an act of parliament and not a treaty. This argument would hold only as long as the scope of the review does not in any way extend to the treaty being approved by the act. ${ }^{109}$ Any exceptions to the prohibition on reviewing the constitutionality of treaties would have to be granted expressly, such as the suggestion by the State Commission to entrust the judiciary with the ex ante power to decide if a treaty violates the Constitution. ${ }^{110}$ Treaties found to be unconstitutional in this manner would consequently have to be adopted by a two-thirds majority, as prescribed in Article 91(3) of the Constitution. ${ }^{111}$ The triggering of this provision is now solely at the discretion of the political branches. In contrast, the proposed judicial review would help place the Constitution at center stage in the adoption of treaties. Even in the absence of such ex ante review, judicial review could still affect the adoption of treaties indirectly. This is because the political branches could draw on the Constitution as judicially clarified and expounded in other cases in grounding their decisions whether to adopt a treaty or not.

Apart from the adoption of treaties, the question of reforming Article 120 of the Constitution can also be studied from the perspective of implementing treaties through acts of parliament. Constitutional review would allow courts to test the exercise of any discretion allowed to the state under international law, such as when it legislates within its margin of appreciation granted by the

\footnotetext{
${ }^{106} I d$. at 4.

${ }^{107}$ See Deirdre M. Curtin, Postnational Democracy: The European Union in Search of a Political Philosophy 51-53, 62 (1997); Ingolf Pernice, Multilevel Constitutionalism in the European Union, 27 EuR. L. ReV. 511,515 (2002).

${ }^{108}$ See Section C.II.2.

${ }^{109}$ Admittedly, the scope of review would be very limited. See Boogaard \& Uzman, supra note 18, at 11 (discussing the prohibition on reviewing treaties). They explain that among other things the intention is to prevent the courts from reviewing the procedure whereby a treaty was concluded. This extends in particular to the question whether a treaty diverges from the Constitution, which would require its adoption by special majority according to art. 91(3) of the Constitution.

${ }^{110}$ State Commission Rep., supra note 7 , at 156 . The State Commission suggested that the power be given to a specially created Constitutional Court.

${ }^{111} \mathrm{Gw}$. [Constitution] art. 91(3) ("Any provisions of a treaty that conflict with the Constitution or which lead to conflicts with it may be approved by the Houses of the States General only if at least two-thirds of the votes cast are in favour.").
} 
ECtHR. A court would have to defer to international law where an implementing act contradicts the Constitution. To do otherwise would be to invert the hierarchy of norms which places international law above national law, including the Constitution. Recalibrating the hierarchy of norms has not been part of the proposals to reform Article 120 of the Constitution. An exception of sorts to this was the proposal in 2010 by some members of the previous State Commission. These members suggested that the core values of the Constitution, whose codification in a special general value provision the whole Commission supported, were to be used to test the direct application of international law found to be binding according to Article 94 of the Constitution. ${ }^{112}$ This would mean that courts may allow international law to supersede national law only to the extent that international law does not contradict the Constitution's values codified in the new provision. A constitutional amendment introducing a shortened version of the value provision proposed by the State Commission is at present making its way through the legislature. ${ }^{113}$ The provision, however, would not allow the courts to test the constitutionality of international law before applying it, as desired by some State Commission members. A codification of core constitutional values could, nonetheless, serve as an aid to the courts commensurate with their powers of interpretation and review in developing a Constitution-based culture.

\section{European Union Dimension}

In addition to national and international elements, the composite constitutional order of the Netherlands also includes an EU component. This component needs to be distinguished from international law. Whereas the monist application of international law, such as the ECHR, is a question governed by national law, courts in the country classify EU law and its monist application as governed exclusively by the EU legal order. ${ }^{114}$ National law does not concern itself with the validity or application of EU law. The situation in the Netherlands is, therefore, quite different from that in countries such as Germany and Poland. Courts in these countries use constitutional identity-type arguments to provide an ultimate national check on the monist application of EU law. ${ }^{115}$ By qualifying the primacy of EU law in this manner, these Member States are viewed as "the masters of the treaties," to use the terminology of the German Federal Constitutional Court. ${ }^{116}$ By comparison, the Netherlands comes closer to Ingolf Pernice's explanation of the $\mathrm{EU}$ as an original legal order based on the sovereign will of the people who constituted it, as opposed to a derivative legal order drawn from national sovereignty. ${ }^{117}$

The special place of EU law in the composite Constitution of the Netherlands could warrant the view that it has no real relationship with the Constitution. This view is aided by the fact that the proposals to reform Article 120 of the Constitution hardly ever discuss the EU law dimension. To exclude EU law from the discussion on the need for reform would, nonetheless, be a mistake, as the Constitution does have a function to fulfill in the context of European cooperation and integration. What can be deduced from the proposals' near-silence on the topic is that reform is not intended to upset the primacy of EU law. The courts will, consequently, not be allowed to judge the constitutionality of acts of parliament to the extent that they implement EU law. Acts of parliament approving EU treaties may likewise not be judged in contravention of the prohibition

\footnotetext{
${ }^{112}$ Rapport Staatscommissie Grondwet, supra note 35, at 36-42, 40, 129-30. The core values identified were the democratic rechtsstaat, human dignity and fundamental rights and principles.

${ }^{113}$ The first reading concluded with the enactment of the Law of March 9, 2018. According to the provision, the Constitution guarantees fundamental rights and the democratic rechtsstaat. See Parliamentary Papers I, 2016-17, 34 516, A.

${ }^{114}$ Hoge Raad der Nederlanden [HR] [Supreme Court], 11 Feb. 2004, ECLI:NL:HR:2004:AR1797 (Rusttijden), para. 3.6 [hereinafter Rusttijden].

${ }^{115}$ See also Monica Claes \& Jan-Herman Reestman, The Protection of National Constitutional Identity and the Limits of European Integration at the Occasion of the Gauweiler Case, 16 GERMAN L.J. 917, 919-28 (2015).

${ }^{116}$ E.g., Bundesverfassungsgericht [BVerfG] [Federal Constitutional Court], Oct. 12, 1993, 89 BVERFGE 155 (Maastricht), 190.

${ }^{117}$ Pernice, supra note 107 , at 518.
} 
on constitutionally reviewing treaties in Article 120 - similar to the position outlined in discussing international law mentioned above. Express powers would need to be created for the judiciary to review EU treaties, such as the State Commission's proposal that such treaties also be subjected to an ex ante judicial check before their approval. ${ }^{118}$ Even in the absence of such reform, judicial review, in other cases, would, at the very least, serve to stimulate a Constitution-based culture. The political branches could then draw on such a culture in deciding whether to approve future EU treaties or not. Moreover, such a culture could guide the intergovernmental participation of the Netherlands in the Council of the European Union as it co-legislates with the European Parliament and in the European Council, which sets the EU's political priorities and direction. ${ }^{119}$

The normative value of national constitutions is also relevant to EU law in other ways. For instance, multilevel constitutionalism for Ingolf Pernice means that the EU is a supranational authority, which is established progressively based on such national constitutions while binding them together in a newly composed constitutional system. ${ }^{120}$ The EU is, therefore, an order reflective of its national orders, at least in part. Article 6(3) of the Treaty on European Union (TEU) recognizes this where it lists the constitutional traditions common to the Member States as one of the sources of fundamental rights in the EU. ${ }^{121}$ The real potential of the Constitution to serve as a source of such tradition is at present sidelined by Article 120. This is because the prohibition on judicial review prevents the development of a strong national culture derived from it, which in turn contradicts the Constitution's function as a cornerstone of national higher law. In addition, the fact remains that the EU is an inchoate and developing constitutional space and one which may never reach full completion. This makes it all the more necessary to recognize the importance of its national ingredients in developing and characterizing the space the EU shares with its Member States. Paradoxically, while Article 4(2) of the TEU even enjoins EU institutions, such as the Court of Justice of the European Union, to respect the "national identities" of the Member States "inherent in their fundamental structures, political and constitutional, inclusive of regional and local self-government," the Netherlands itself is reluctant to allow its courts the same powers. ${ }^{122}$

\section{Beyond Exceptionalism}

The democratic rechtsstaat, as the typical characterization of the constitutional order of the Netherlands, is an abstract value that comes to life through its expression in principles and rules. ${ }^{123}$ The Constitution is but one, yet important, cog in the normative edifice erected to realize the rechtsstaat and its democratic structures. In realizing and protecting this cog, the cumulative effect of the discussion in this part has been to show the theoretical and practical shortcomings of the prohibition on review in Article 120 in securing constitutional normativity. Allowing the courts to review acts of parliament will go a long way to improve the situation in a hard or direct way by not applying acts that contravene the Constitution. Importantly, judicial review will also promote constitutional normativity in a soft or indirect way. ${ }^{124}$ All too often, the radiating and

\footnotetext{
${ }^{118}$ State Commission Rep., supra note 7, at 156. This would be similar to the check the State Commission suggested for nonEU treaties. A finding of unconstitutionality would require the legislature to adopt the treaty with a special majority, as required in art. 91(3) of the Constitution.

${ }^{119}$ In the Dutch context the Dutch Constitution would serve as a source of influence, rather than of judicially enforceable and binding norms, as in the German context.

${ }^{120}$ Pernice, supra note 107, at 514-15.

${ }^{121}$ Consolidated Version of the Treaty on European Union art. 6(3), Sept. 5, 2008, 2008 O.J. (C 115) 15 [hereinafter TEU].

${ }^{122} \mathrm{TEU}$ art. 4(2). On this provision, see Gerhard van der Schyff, Exploring Member State and European Union Constitutional Identity, 22 EUR. PUB. L. 227 (2016).

${ }^{123}$ See Maurice Adams, Constitutionele geletterdheid voor de democratische rechtsstaat, NEDERLANDS JURISTENBLAD 17, at 874 (Apr. 26, 2013).

${ }^{124}$ Consider also the distinction drawn by Wojciech Sadurski, Judicial Review and the Protection of Constitutional Rights, 22 OXFORD J. LEGAL STUD. 275, 287 (2002) between promoting the consideration of rights and legislation and of pro-rights attitudes in a wider context.
} 
mediating effect of the Constitution, as a source of culture and justification, is overlooked in debating the benefits of judicial review. ${ }^{125}$ Rather, the focus of the debate falls on review as an immediate check on the legislature to enforce rules. In this regard, the State Commission's emphasis on reinforcing the Constitution's "societal significance" through judicial review is to be welcomed. ${ }^{126}$ Promoting "constitutional literacy," as it has been called, through the courts could bolster the Constitution's relevance in all its spheres of application, be they national, international, or EU-related. ${ }^{127}$ To leave the prohibition intact would serve only to make an anomaly of the Constitution and prove correct predictions that the latter threatens to lose its force of law, thereby becoming a dead letter. ${ }^{128}$ Far from being an example to emulate on the comparative stage, Dutch exceptionalism on constitutional review is one to be avoided.

\section{Roadmap for Reform}

Supporting the reform of Article 120 of the Constitution implies a duty to recommend how such reform can be achieved, especially in the Dutch context, where attempts at reforming the prohibition on constitutional review have been synonymous with failure. Ironically, while the prohibition on judicial review has been an obstacle to realizing the normativity of the remainder of the Constitution, the provision's own normativity has proved tenacious, providing resistance to reform. The normativity of Article 120 cannot be ascribed to the provision being unamendable as a matter of constitutional law or theory, as the Constitution is generally viewed in positive law terms and as such amendable in its entirety. ${ }^{129}$ Also, the reason for the absence of reform does not seem to be rooted in the proposals being overly ambitious or far-reaching in upsetting legislative primacy. If anything, the proposals for reforming Article 120 of the Constitution have been measured in their ambition. Furthermore, there are cogent reasons to support reform. Instead, the failure to achieve change should probably be sought in the circumstances under which constitutional reform usually takes place in the Netherlands. In this regard, the country's Constitution often registers an existing practice as higher law, instead of driving societal and political change-such as the transformative Constitution of South Africa, for instance. ${ }^{130}$ Legislative reluctance, and even inertia at reform, in the Netherlands would seem to decrease, to the extent that reform applies or extends existing constitutional logic or practice. ${ }^{131}$ This ties in with the description of a constitutional amendment as the continuation of "the constitution-making project in line with the current design." 132 This thinking bodes well for the inclusion of the earlier

\footnotetext{
${ }^{125}$ On "constitution as culture," see Günter Frankenberg, Comparing Constitutions: Ideas, Ideals, and Ideology-Toward a Layered Narrative, 4 INT'L J. CONST. L. 439, 449-50 (2006).

${ }^{126}$ State Commission Rep., supra note 7, at 149.

${ }^{127}$ See Adams, supra note 123 (regarding the concept and its relevance to the Netherlands).

${ }^{128}$ Cf. W.J. Witteveen, Evenwicht der machten 86-87 (1991) (warning that art. 120 will turn the Constitution into an anomaly).

${ }^{129}$ BURKENS ET AL., supra note 14, at 127 (explaining that because the Constitution has always been regarded as positive law, there is no definite legal protection against the scrapping of its fundamental rights). On the topic of constitutional (un)amendability, see generally YANIV RozNAi, UnConstitutional Constitutional AMENDMENTs (2017); David E. Landau, Rosalind Dixon \& Yaniv Roznai, From an Unconstitutional Constitutional Amendment to an Unconstitutional Constitution? Lessons from Honduras, 8 Global Const. 40 (2019); Silvia Suteu, Eternity Clauses in Post-Conflict and Post-Authoritarian Constitution-Making: Promise and Limits, 6 Global Const. 63 (2017).

${ }^{130}$ E.g., DRAGSTRA ET AL., supra note 27, at 27 (explaining that the 1983 major constitutional revision codified a number of elements which developed independently of the Constitution, while pointing out that the document is still incomplete in this respect by not codifying a number of other important constitutional rules).

${ }^{131}$ For example, the inclusion of socio-economic rights in the Constitution in 1983 can be understood as a logical consequence of protecting fundamental rights, starting with the inclusion of express classical rights in 1848, and not as something novel.

${ }^{132}$ Richard Albert, Constitutional Amendment and Dismemberment, 43 YALE J. INT'L L. 1, 3 (2018) [hereinafter Albert, Constitutional Amendment and Dismemberment]. See also Richard Albert, Constitutional Amendments: MAKing, Breaking and Changing Constitutions (2019) [hereinafter Albert, Making, Breaking and Changing].
} 
mentioned general value provision in the Constitution, as it would codify the existing values of the democratic rechtsstaat and fundamental rights. The amendment would, in effect, "elaborate" on the Constitution by advancing its meaning as presently understood. ${ }^{133}$

Unfortunately, this knowledge provides little comfort in reforming Article 120. Instead of continuing the Constitution's meaning or design, revising the provision would come close to a "constitutional dismemberment" by "disassembling" a structural feature of the Constitution. ${ }^{134}$ This is because qualifying the rule that courts may not review the constitutionality of acts of parliament would indeed be novel. If the nature of constitutional reform in the Netherlands is anything to go by, the odds of such reform succeeding are low indeed. Options to break the deadlock would range from relaxing the rigid constitutional amendment procedure to ease reform, to simply waiting for either a legislative epiphany or perhaps even a political system rupture of near revolutionary proportions in favor of reform. ${ }^{135}$ Although nothing can ever be ruled out, these options seem unrealistic. The route to reform must be sought somewhere else.

The sketched situation presents a conundrum. Reform of Article 120, to have a realistic prospect of success, should ideally reflect an existing practice of the courts reviewing the constitutionality of acts of parliament. The provision would seem to stand in the way of such a practice from taking root. But this would be the case only to the extent the debate on Article 120 conflates constitutional change with reform, understood as a procedural change of the Constitution on the basis of the formal amendment procedure in article $137 .{ }^{136}$ This conflation consequently views the legislature as possessing a monopoly in bringing about any change to the provision. Although correct as to the wording of Article 120, this view is arguably too legal-positivist in over-concentrating on the amendment procedure as the appointed avenue for reform. ${ }^{137}$ The reason for this criticism is that other types of constitutional change might be neglected in understanding or developing Article 120's scope of application. More instructive is the insight by Dawn Oliver and Carlo Fusaro that the concept of change can also be understood informally as an evolution or development in state bodies' practice, in addition to formal change. ${ }^{138}$ The effect is to appreciate that the Constitution is interconnected with its institutional context in generating meaning through time. ${ }^{139}$ Once this is realized in relation to Article 120, questions can be put about the role of the courts' practice in promoting and protecting the Constitution.

Viewed from this perspective, more room exists for the courts to act in respect of the Constitution than might have originally been thought. Specifically, courts could develop a practice of weak constitutional review. In this regard, they could follow the example set by the Supreme Court in the Harmonisatiewet case where it signaled a violation of a fundamental legal principle while still applying the offending act of parliament. ${ }^{140}$ By not practicing weak review,

\footnotetext{
${ }^{133}$ Albert, Constitutional Amendment and Dismemberment, supra note 132. Apart from "elaboration," Albert also describes "correction." The latter type of amendment corrects an "error" or "flaw" in the Constitution, but in a manner respectful of its design.

${ }^{134} \mathrm{See} i \mathrm{i}$. at 4 . In depicting the nature of constitutional change in the Netherlands, "dismemberment" is used here in a descriptive sense, a "phenomenon" as Albert calls it. Its use for present purposes does not pertain to "dismemberments" as a theoretical counter-pole to the notion of "unconstitutional constitutional amendments." Id. at 8, 84 .

${ }^{135}$ On constitutional moments in this context, see Gerhard van der Schyff, Constitutional Review by the Judiciary in the Netherlands: A Bridge Too Far?, 11 GERMAn L.J. 275, 284-88 (2010). See also, supra note 41 on the constitutional amendment procedure and the discussion related to it.

${ }^{136}$ Reform in this sense corresponds to the definition of a "constitutional amendment" used by Rosalind Dixon, Constitutional Amendment Rules: A Comparative Perspective 96, 97 (University of Chicago Public Law \& Legal Theory, Working Paper No. 347, 2011) as "processes of constitutional amendment" that "involve legislative and popular involvement" and "formal change to the text of a written constitution."

${ }^{137}$ See Reijer Passchier, Formal and Informal Constitutional Change in the Netherlands, in The DutCH CONSTITUTION BEYOND 200 YEARS, supra note 26, at 153, 160-61.

${ }^{138}$ See How Consituions Change, supra note 61, at 429.

${ }^{139}$ Passchier, supra note 137 , at 163 (referring to the "historical-institutionalist" view).

${ }^{140}$ See Section B.I.
} 
courts are as much shapers of the conventional position that Article 120 of the Constitution encompasses both strong and weak review, as they are followers. Instead of being followers, courts should arguably emulate the judgment when necessary to protect the Constitution. Arguments based on legislative primacy could then be used by the courts to decide the scope and intensity of their review, rather than justification for an absolute prohibition on review. In any event, weak review should at least require a more critical attitude in interpreting whether acts of parliament are in conformity with the Constitution, rather than simply giving the legislature the benefit of the doubt. ${ }^{141}$ To do otherwise would be to emphasize a notion of the strict separation of powers not only superseded by treaty review, but one whose reliance on the doctrine of legislative primacy is open to sustained criticism. The need to ensure a living Constitution, relevant in its fields of composite application, is as much the duty of the courts as it is their executive and legislative partners. On this reading, there is no need for the courts to wait for weak review to be introduced, as the Cabinet hinted it might propose in reflecting on the report by the State Commission.

The path to reforming Article 120 of the Constitution of the Netherlands should start with the courts, and not with the legislature as has been the impression to date. The courts have an opportunity, and even a duty, to use weak review to build a solid practice of constitutional promotion and protection. The legislature could then choose how best to record the courts' practice of such review, and whether its logic should be extended to include the strong review of acts of parliament.

True to the nature of amending the country's Constitution, Article 120 is a prime candidate for developments in institutional practice leading to constitutional reform, instead of the other way around.

\footnotetext{
${ }^{141}$ Dutch courts could draw inspiration from New Zealand courts applying $\$ 6$ of the 1990 Bill of Rights Act, or British courts applying $\$ 3$ of the 1998 Human Rights Act—the point of departure for comparative purposes being that strong review is not exercised. Taking note of the same caveat, Dutch courts could also draw on their experience in conducting treaty review. See Uzman, supra note 27 for an investigation of their remedial powers in this regard.
}

Cite this article: van der Schyff G (2020). The Prohibition on Constitutional Review by the Judiciary in the Netherlands in Critical Perspective: The Case and Roadmap for Reform. German Law Journal 21, 884-903. https://doi.org/10.1017/ glj.2020.45 